\title{
"Byronic" Phraseological Units and Their Equivalents in the Armenian Translation
}

\author{
Ofelya Poghosyan, Varduhi Ghumashyan \\ Yerevan State University
}

\begin{abstract}
The article highlights one of the most typical features of G.G. Byron's individual style, particularly, the use of a great variety of phraseological units in his works. The basic layer of Byron's literary vocabulary includes phraseological units derived from the Bible and Greek mythology.

The present article focuses on the problem of translatability of the so-called "Byronic" phraseological units in his narrative poem Childe Harold's Pilgrimage.

It is an acknowledged fact that Byron's works are translated into numerous languages and the Armenian translations have their special place among them. The eminent Armenian writer H.Tumanyan succeeded in finding the best equivalents of "Byronic" phraseological units that not only sound convincing, truthful and colourful, but also very often enrich both the source and the target languages.
\end{abstract}

Key words: phraseological units, idioms, source language (SL), target language (TL), narrative poem, individual style, intranslatability.

\section{Introduction}

Language and culture are connected dialectically. Language is a means of expression of one's identity. It is impossible to understand a foreign language unless you at least have some idea about the conditions the nation speaking the language lives in. In other words, real use of linguistic elements in speech and speech productivity are conditioned by the knowledge of the social-cultural life of the people speaking the language. Rituals, traditions, customs are closely 
connected with language, as they form part and parcel of linguocultural realia (Edward 1990).

The reflection of the dialectical connection between language and culture is revealed in the study of phraseological units in general and their translations from SL into TL in particular. From this viewpoint it is of paramount interest to study the means of translating "Byronic" phraseological units from English into Armenian.

The translation of English phraseological units that express the same meaning and have their adequate forms in the Armenian language does not put forward any problems, therefore in this study the emphasis is laid on the translation of phraseological units with no equivalents in the Armenian language and culture at all. In the article we also make an attempt to analyse phraseological units that are similar in meaning but different in form in the English and Armenian languages. Thus, this work is another attempt to shed light on some disputable and problematic issues in the art of translation, particularly focusing the attention on the problems of intranslatability.

The abundance of linguistic forms, language structures and the rich word stock of the Armenian language are powerful means for translators to skillfully and adequately do translations from other languages, irrespective of their complicated linguistic and cultural differences.

\section{On the Differences and Similarities of Phraseological Units in SL and TL}

Being natural human languages English and Armenian, as well as other languages, have interesting similarities either in their forms or meanings or in both of them. Nonetheless, there are vast differences, especially those of linguocultural nature. The reflection and impact of culture, its customs and traditions on language formation is great as these factors have their direct influence on the thought, mentality, outlook of people and very often give birth to innumerable language phenomena.

Phraseological units or idioms, as defined by some western scholars, represent what can be considered as the most picturesque, colourful and expressive part of the language vocabulary. Phraseology may be described as a 
kind of picture gallery where are collected bright and amusing sketches of the nation's customs, traditions and prejudices, recollections, memories of its past history, scraps of folk songs, stories and fairy-tales (Antrushina 1985:173).

In our article the terms phraseological unit and idiom are used interchangeably taking into account the definition given by G. Antrushina, although the term phraseological unit has a broader meaning than the term idiom. Idioms are specific to one culture and language and their meaning is peculiar to that particular language (The Oxford Dictionary of English Etymology, 1966). When idioms in one language are translated into other languages, they may sometimes lose their actual meaning because many idioms are specific to a particular culture (The Universal Dictionary of the English Language, 1958).

According to Gibbs (1992) the meaning of idioms is more emphatic than that of their equivalent literal paraphrases. They convey more complex meaning entailments and implicatures at once than single word paraphrases express in several sentences. Idioms have complex meaning that seems to be motivated by independently existing lively and creative conceptual metaphors that are able to reflect the complexity of human thought better than single words can. Therefore, Gibbs disclaims the presumption that idioms are dead metaphors. Idiomatic figures convey not only factual meaning but also particular evaluative aspect towards the relevant phenomenon (http://philologica.net/).

In Linguistics, idioms are usually presumed to be figures of speech contradicting the principle of compositionality. That compositionality is the key notion for the analysis of idioms emphasized in most accounts of idioms. This principle states that the meaning of a whole should be constructed from the meanings of the parts that make up the whole, whereas in idioms this key notion is violated (http://en.wikipedia.org).

As far as the English phraseological units or idioms in Childe Harold's Pilgrimage and in their translations into Armenian are concerned, our analysis shows that to a certain extent they can be identified by their origins that are in most cases either from the Bible or Greek mythology. However, there are also idioms the sources of which are difficult to be found. Presumably, it can be 
stated that this phenomenon is connected with our ancestors' cultural and traditional habits that are not actual today, consequently their origin still remains unknown.

Finding solutions to problematic situations the Armenian writer managed to translate innumerable idioms totally preserving the meaning of the original. Moreover, there are some passages where an ordinary sentence or a word combination is translated into Armenian as an idiom which makes the translation not only beautiful but also adequate.

In order to have a clear idea of what has been said it is necessary that some phraseological units from Childe Harold's Pilgrimage be analyzed and compared to their translated versions in Armenian.

Phraseological units in general are formed through the medium of different stylistic devices (Gibbs 1992). The study and analysis of some translation problems in Childe Harold's Pilgrimage brought us to the conclusion that in the poem there is a special layer of vocabulary which consists of a great number of phraseological units created on the basis of metaphor and metonymy. These units can be called metaphoric or metonymic phraseological units whose number in the poem is prevailing.

The translation of the following extract has preserved the function of aesthetic impact, the expressiveness and exquisiteness of Byronic language. In this respect it is interesting to analyse the following lines from the poem:

\section{Who lick yet loathe the hand that waves the sword \\ To save them from the wrath of Guald's unspoiring lord.}

(Byron 1956, I-XVI:55)

There are two phraseological units in the example: to lick the hand and to wave a sword. To lick the hand means to cajole, to accept the defeat, and the second unit to wave a sword is associated with the concept war.

In the English-Russian Phraseological Dictionary by A.Kunin (1984) the unit to lick smb's boots (or shoes), means to be servile towards somebody; it conveys a meaning close to that of to lick the hand as both of them mean to accept 
other's requirements, wishes, commands neglecting selfesteem, one's own standpoints.

It is interesting to note that metaphoric and metonymic phraseological units are found not only in the original source but also in the target language.

Lick ... hand and Wave ... sword are metonymic phraseological units. By saying to lick a hand we understand: asking somebody for something in the way a dog usually does when asking its owner for something. In other words, the phrase depicts the image of a servile person or servility. As far as the phraseological unit to wave a sword is concerned, the word sword in this context substitutes the concept of war.

Both phraseological units are translated into TL very adequately:

\section{Lhqkg inn Luipny uj di dinpz ounup,

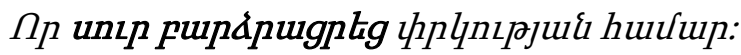

Due to his fundamental philological knowledge, creative approach, flight of thought, perfect awareness of the culture, language and history, the translator succeeded in transferring not only the content of the work and the author's thoughts but also the original form of the text which is understood as a complex of means expressing the content.

\section{The Study of Phraseological Units of Linguocultural Nature}

It goes without saying that a translator has no difficulty in translating phraseological units which exit both in SL and TL reality. An interesting question arises in this respect: what is the origin of similar phraseological units in different languages? Presumably, it is connected with the existence of similar linguocultural realities in SL and TL. Nevertheless, for answering this question further studies are still expected to follow.

An interesting example to illustrate an adequate translation of a phraseological unit is as follows: 


\section{Pour'd forth his blood}

Beneath the assasin's knife

Some hand erects a cross

Of mouldering lath;...

The phraseological unit to pour blood or to shed blood means to kill somebody. It is easily and adequately translated into Armenian as it expresses the same meaning in similar contexts both in SL and in TL. It is a metonymic phraseological unit expressed by a verbal construction which conveys the meaning of the scene of murder. In the Armenian version it effectively transfers the aesthetic impact it has in the original text. However, the question which language this or that phraseological unit originated in still remains unanswered.

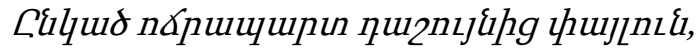

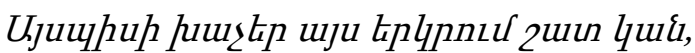

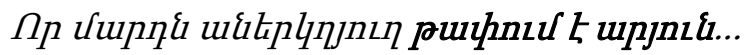

The next example adduced from Childe Harold's Pilgrimage runs as follows:

$$
\begin{aligned}
& \text { And marvel mens should quit their eary chair, } \\
& \text { The toilsome way, and long, long league to trace... }
\end{aligned}
$$

The phraseological unit to quit eary chair in this extract means to make no attempt to improve the situation. It is a metaphoric phraseological unit whose meaning is totally preserved in the translated version of the phrase ( $q u \downarrow \downarrow u u \delta$ upnnhi).

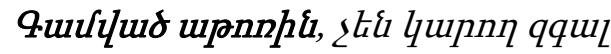

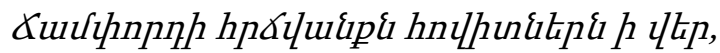

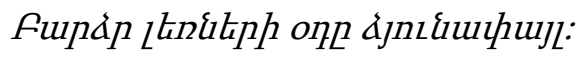


In the Armenian language the direct meaning of the phrase quulyur upnnhi is stuck or clung to the chair which certainly cannot be considered appropriate in this context. However, its metaphoric interpretation is equivalent to quit their eary chair.

The phraseological units in the following passage have totally preserved their meaning in the Armenian version.

\section{And Vice that digs her own voluptuous tomb \\ Had buried long his hopes, no more to rise. \\ (I-LXXXIII:77)

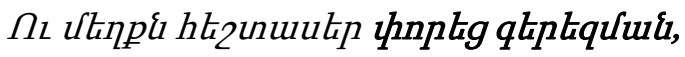 \\ Suikitny hp htiu hnujukp yupnuqnug:}

The units to dig a tomb (that transfers the meaning of the verb to bury) and hopes, no more to rise (which means hopes that will never come true) are metaphoric phraseological units whose meaning is adequately transferred from SL to TL as both exist in the English and Armenian linguocultural realities.

\section{The Translation of Biblical Phraseological Units}

The unit curst Cain's unresting doom is an example derived from the Bible:

\section{Pleasure's palled Victim! Life-abhorring Gloom \\ Urote on his faded brow curst Cain's unresting doom.} (I-LXXXIII:77)

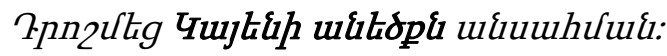

Cain's curse is an idiom whose source in both languages is the Bible, hence its translation in TL is precise and adequate. Cain is a cursed character in the Bible; G. Byron was much interested in this character, thus, it is not accidental that later he wrote the misteria Cain. 
Another biblical phraseological unit is found in the following example:

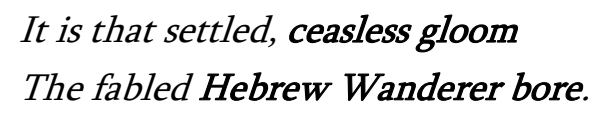

Its equivalent version in the Armenian language is as follows:

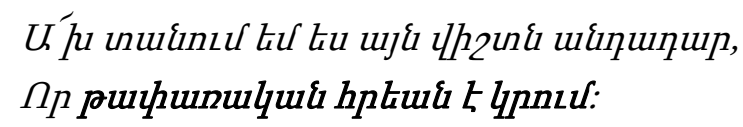

(I-Inessin:132)

Hebrew Wanderer (pulhunulyuis hpluu) is an idiom that exists in Christian and Israelite traditions and is used both in English and Armenian. A Hebrew Wanderer is a person with an extraordinary destiny that attracted Byron's attention.

Let us consider the following example:

Or fear their name defiled from Slavery's mournful page.

(II-LXXV:114)

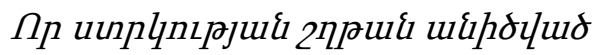

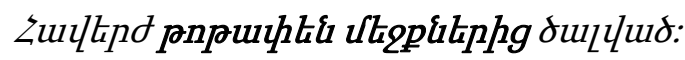

The phraseological unit slavery's mournful page is translated into Armenian

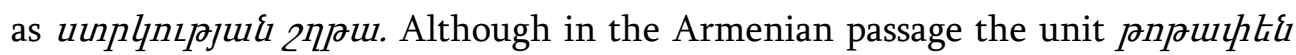
Utigpilinhg (to take away the burden, to get free of the burden) is not the adequate form of the phraseological unit in the source language (slavery's mournful page), the meaning of the original is totally preserved in the Armenian version. In other words, there are situations when this or that phraseological unit in SL does not have its equivalent form in TL, hence the 
translator has either to paraphrase it or give its descriptive translation in order to preserve the idea expressed in the original text.

\section{Byronic Phraseological Units}

In the following extract silent sea is an individual authorial or Byronic phraseological unit.

Something too much of this: - but now tis past, And the spell closes with its silent seal.

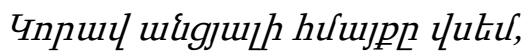

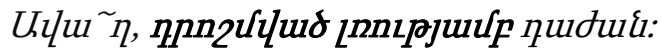

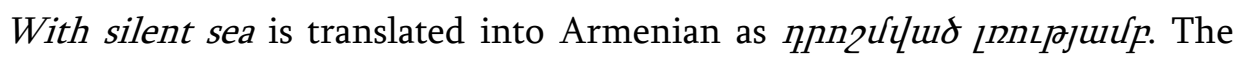
phraseological units created by a particular writer are called individual authorial units. This kind of phraseological units enrich not only the target language, but also the source language from which they are translated.

It is well known that a writer often describes or writes about this or that mythological and religious fact, the memories that have remained in his/her consciousness. Consequently, it can be assumed that the phraseological unit silent seal is connected with a certain old religious ritual, which was stamped in the poet's memory. In this respect Fon Humboldt states that there are writers who due to the moments of strong inspiration can give or inject some new, additional characteristics to the language of their creative work (Humbol'dt 1985:372). In the passage to follow the whole scene, its beauty and expressiveness is adequately transferred from English to Armenian.

Stop! For tread is on an Empire's dust!

(III-XVII:156)

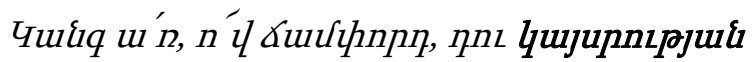

¿nqu ku nupp qinul... 
In the Armenian translation of the phraseological unit tread is on an

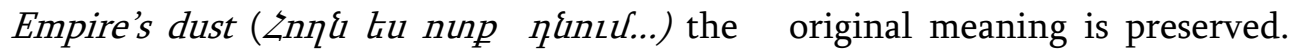
However, difference between them is revealed. In the Armenian language $h n \eta$ means soil but it also conveys the meaning of the word land which in this context stands for an Empire's dust.

The word- combination tread is on an Empire's dust comes to mean that someone's foot stepped on the land of the Empire. In fact, it is an idiom whose source is considered to be connected with war tradition as it symbolizes the winner who puts his foot on a new land or the invader who occupies a new land. Thus, even though in this passage there is no similar phraseological unit in $\mathrm{TL}$, the translated version conveys the meaning of the extract adequately.

\section{The Interplay of the Categories of Part and Whole in the Art of Translation}

Here comes another example with a breathtaking description of the nature of divine love and beauty.

\section{.........and the bend \\ Of stirring branches, and the bud which brings \\ The swiftest thought of Beauty here extend \\ Mingling-and maok fy Love-unto one mighty end.

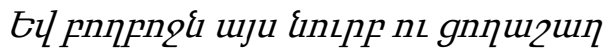

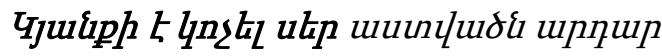 \\ nz dnıl'l uhujuigg 'qjuikph huviup:}

(III-102:207)

The word-combination maok fy Love which means made by love expresses the meaning of creating something for happiness. The Armenian translation in general conveys the beautiful description of love in the original text.

At first sight it may seem that the image of the whole scene is successfully and adequately transferred to TL, however, in this respect some observations should be made. It is well-acknowledged that in adequate translations the 
meaning of a text may be adequately transferred due to a proper choice of the constituents the text is constructed with.

The phraseological unit lJuilph hnzk ( to bring to life) is used to substitute the English word-combination made by Love or created by Love which can at least be observed as a set-phrase but not as an idiom. In fact, the translator transfers this meaning with the help of the idiom lJukph $q_{1}{ }^{2} l_{L}$ which partially reveals the idea that the basis of happiness and beauty is Love. Hence, on the whole the translator managed to transfer the meaning of the original. However, it cannot possibly be described as adequate translation.

In the following extract another interesting word-combination is revealed:

I saw from out the wave her structures

As from the stroke of the rise Enchanter's wand...

(IV-I:206)

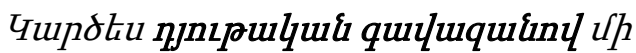

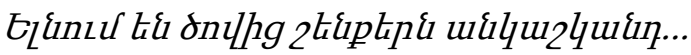

The set-expression Enchanter's wand is translated into Armenian as пjnцpuluu\{ quцluqui. The word enchanter prompts us to think that the source of the phrase should be searched in fairytales, myths or the Bible. The Armenian translation is done adequately as it conveys not only the meaning of the set-expression but also that of the whole passage. However, we can observe that although the translation is done adequately, in the English version the stress is put on the word stroke but in the Armenian translation it falls on the set-expression Enchanter's wand. Presumably, this phenomenon can be explained by the differences in the linguocultural reality of the writer and the translator. 


\section{Conclusion}

Thus, it can be assumed that the translations of phraseological units, particularly idiomatic expressions from the source language into the target language are carried out by using the following strategies:

a) using an idiom of similar meaning and form. This strategy involves using an idiom in the target language which conveys roughly the same meaning as that of the source language idiom, and, in addition, consists of equivalent lexical items. The sources of this kind of idioms from Childe Harold's Pilgrimage are either from the Bible or Greek mythology.

b) using an idiom of similar meaning but not form. The idiom in the target language is transferred through the medium of idiom or expression consisting of lexical units different from those in the source language.

c) using paraphrasing is the most common way of translating idioms. It takes place when a match for this or that idiom cannot be found in the target language, or when it seems inappropriate to use idiomatic language in the target text because of differences in stylistic preferences of the source and target languages.

d) idioms are a colourful and fascinating aspect of any language and their abundant use is found in G. Byron's works.

e) "Byronic" linguomentality is chiefly based on metaphorical thinking and interpretation of reality.

f) The linguostylistic connotations of linguistic units are adequately transferred into the Armenian language due to $\mathrm{H}$. Tumanyan's brilliant sense of language world, art of translation and excellent awareness of cultures in general.

\section{References:}

1. Antrushina,G.B. (1985) English Lexicology. M.: Drofa Press.

2. Edward, J. (1990) Understanding Cultural Differences. Yarmouth, ME: Intercultural Press. 
3. Ghumashyan, V.S. (2010) George Gordon Bayroni hayeren targmanutyunneri lezun. Candidate Disertation. Yerevan: RA NAS.

4. Humboldt, V. (1985) Yazyk i kul'tura. Yazykovaya kartina mira. M.: Visshaya Shkola.

5. Kunin, A.V. (1970) Angliyskaya frazeologiya. M.: Visshaya Shkola.

6. Kunin, A.V. (1984) English Russian Phraseological Dictionary. M.: Russkiy Yazyk.

7. (1997) Oxford Dictionary of English Idioms. Oxford: OUP.

8. (2005) Oxford Dictionary of Foreign Words and Phrases. Oxford: OUP.

9. Soukiasyan, A.M.; Galstyan, M.A. (1975) Hayoc lezvi dardzvatsabanakan bararan. Yerevan: Yerevan University Press.

10.The Encyclopedia of Dormat Languages. Available at: <http:// philologica.net/studia/2000308140000.htm> [Accessed May 2018].

11. Wikipedia. Available at: http://en.wikipedia.org/wiki> [Accessed May 2018].

12.Yezekyan, L. (2008) Hayoc lezvi vochagitutyun. Yerevan: Yerevan University Press.

\section{Sources of Data:}

1. Bayron, G.G. (1965) Yerkeri zhoghovacu. Yerevan: Hayastan Press.

2. Bayron, G.G. (1985) Polomnichestvo Chaylda Garolda. Moskva: Pravda.

3. Byron, G.G. (1862) Childe Harold’s Pilgrimage. Leipzig: Bernhard Tauchnitz (Harvard College Library).

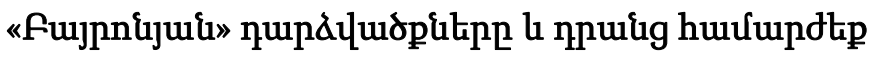 pupqưuinıpjnılap hujteptinıu}

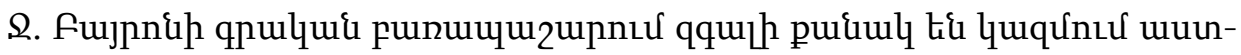

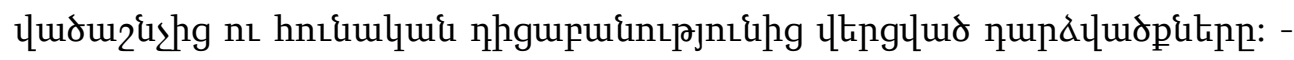




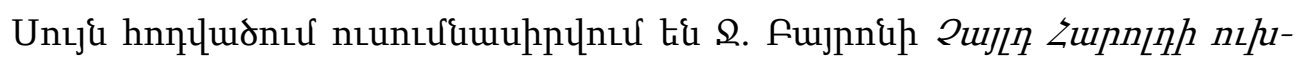

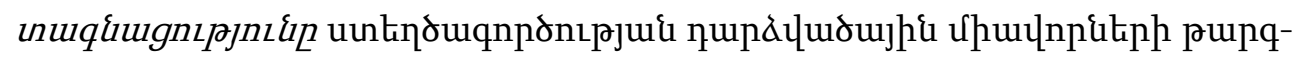

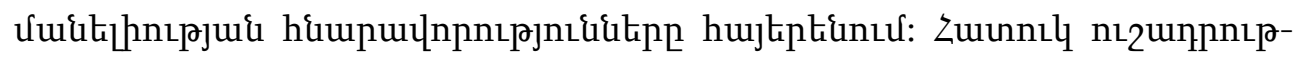

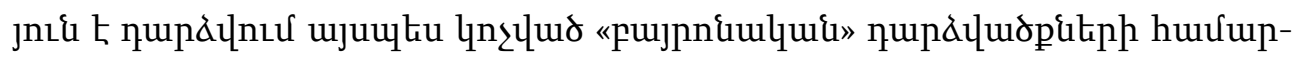

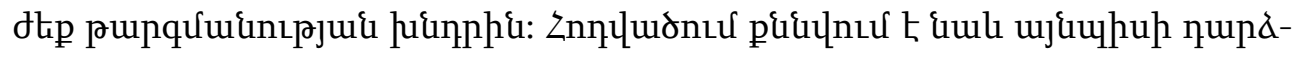

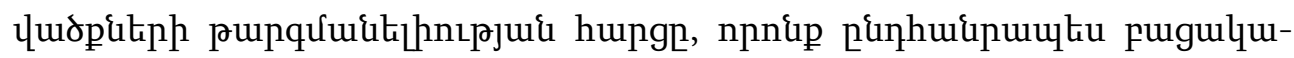

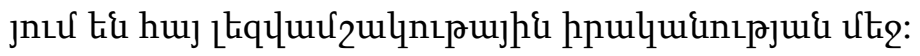

